JOURNAL OF SECURITY AND SUSTAINABILITY ISSUES

ISSN 2029-7017 print/ISSN 2029-7025 online

2020 March Volume 9 Number 3

https://doi.org/10.9770/jssi.2020.9.3(13)

\title{
FACTORS OF REGIONAL SYSTEMS COMPETITIVENESS
}

\author{
Duiskenova Raigul ${ }^{1}$, Zhumaxanova Karlygash ${ }^{2}$ \\ ${ }^{1}$ Kazakh Humanitarian Juridical Innovative University, EKR, Semey, Mangilik el str, 11, Semey, Kazakhstan \\ Kazakh automobile and road Institute named after L. B. Goncharov, Almaty, Kazakhstan \\ E-mails: ${ }^{1}$ raigul19@mail.ru; kmuratovna2019@mail.ru
}

Received 25 February 2019; accepted 26 November 2019; 30 March 2020

\begin{abstract}
National competitiveness is a multisided concept that includes a system of indexes, indicators, criteria, conditions and factors of development, mechanisms of its improvement. Competitiveness consists of a number of components that supplement each other and ensure steady economic growth, improving the welfare of the population. These are: science and education, innovation and investments, various infrastructure, real economy sector, small business, various services, natural and human resources. The objective of necessity to perform reforms at the regional level and the natural increase of the role of the regions in reforming the economy are predetermined by the fact that the ability of state bodies, ministries and departments to influence the course of reforms is gradually limited, and the new market mechanism is not working enough effectively yet. This shows the necessity of determination of the role and place of the region in the economic space, its potential possibilities and development prospects.
\end{abstract}

Keywords: economy; region; factor; conditions; competitiveness; measures; approaches; analysis; territory; groups; mechanism; interaction

Reference to this paper should be made as follows: Raigul, D., Karlygash, Z. 2020. Factors of regional systems competitiveness. Journal of Security and Sustainability Issues, 9(3), 877-886. https://doi.org/10.9770/jssi.2020.9.3(13)

JEL Classifications: $\mathrm{O} 10$

\section{Introduction}

The main aim of the executive authorities in the regional economy is to provide the population with a sufficiently high and decent standard of living level. The ability of regional and local government bodies to do so depends on how much their own resources are productively used - labor and capital. Representatives of the regional authorities are fighting at the level of state bodies for providing the region with more favorable economic conditions in comparison with others, lobbying the interests of large structure-forming enterprises of the region, looking for a possibility for independent establishment of international relations, trying to protect local producers with administrative measures (Abylkasimova et al., 2019).

There is a competition between regions, although it takes place in different forms and has got a bit different consequences than at the micro and macro levels. This can be seen in the case of the main entities of the region, when the enterprises of the region compete: a) within the region with each other; b) within the region with enterprises of other regions and countries; C) with competing regions; d) in the CIS market and the world market (Alina et al., 2018; Tvaronavičiené, 2019).

It is necessary to add the following: it is impossible to count on reasonably high competitiveness of the region if the basic balances of political, social and economic character are not regulated. In this regard, we can state with confidence that the main level of competitiveness - macroeconomic, which determines the basic conditions for the functioning of the whole economic system in the region (Mizanbekova, Mizanbekov, 2018). 


\section{Methods of research}

For each region, it is important to know what factors contribute to improve competitiveness in order to be able to manage them, and to refuse unpromising competition in those areas where there are almost no chances of attracting or preserving the consumer.

The world Economic Forum in the TACIS programme published the "Structure of competitiveness factors" which in our opinion can serve as a model or starting point for determining the policy directions of the region to improve its competitiveness: government; internal economic strength; infrastructure; science and technologies; availability and qualification of human resources; finances and financing; management; internationalization.

Except the selected factors that determine the direction of the formation of regional policy, forms of construction (organization) of business make significant influence to the competitiveness: diversification; restructuring; clustering. However, in the composition and formulation of the factors that determine the competitiveness of the region competitiveness has a high social and economic significance (Tireuov et al., 2019).

The driving forces that determine the competitive position of the region are: clusters, social and entrepreneurial corporations, special zones; human resources; business environment of enterprises work, difficulty of the tax burden; innovation (regional innovation systems - business incubators, technology parks, technopolises, etc.); regional management, management and institutional possibilities; sectorial structure of the region, types and forms of enterprises; production and social infrastructure; typology of regions and the level of integration of firms; internationalization of the region; attractiveness for investment; geographical and geopolitical position (Ohotina et al., 2018; Kiseláková et al., 2018; Petrenko et al., 2019; Amraoui et al., 2019; Bublienè et al., 2019).

\section{The discussion of the results}

In the new social and economic environment, the competitiveness of entities at all levels of the economic system depends on the synergetic effect provided by a wide range of specialized industrial, technological, financial, commercial, administrative and cultural possibilities, knowledge and skills located in different regions of the world. Nowadays social capital of the territories which attracts more attention of scientists and practitioners makes a significant contribution to the general effect.

It differs from other forms of human capital as it is created and transferred through cultural mechanisms, national mentality and accumulated more difficult than other forms of human capital. Social capital is unequally distributed among different societies and territories and these differences have got an impact on economic development of the territory.

It is necessary to consider the competitiveness of the region as a phenomenon which is dynamically developing in time. This means that various factors perform the role of "driving force" at different times and for different regions (Dudin et al., 2019). A systematic view of the competitiveness of the region has allowed us to discover possible approaches to the definition of factors. The main groups of factors to which the information component is added today are identified from the viewpoint of the resource approach. Focusing on the entities of economic activity gives an understanding of the role of participants in regional production in the national economy.

The appeal to structuring predefines appearance of structural factors that describe regional economy and its infrastructure. Another approach to the development of the regional system reveals in it the institutions that determine the regularities of functioning, the principles of work that assign possibilities and limitations.

The indicated approaches and their substantiating criteria are presented in some degree in the existing lists of factors of regional competitiveness. It is especially necessary to position the factors that arise not as a consequence of existence of business entities and facilities but as result of emergence and keeping of interactions between them and as the mechanism of interdependence at the level of vertical and horizontal communications. 
Analysis of development trends of business competitiveness showed that the relationship between economic agents in the modern world in order of importance come to the fore. However they are practically absent in all scientific works or given within the framework of resource, structural groups. Our vision of the region's competitiveness factors is given in the form of a classification (table 1).

Factors of competitiveness can be divided into external and internal. In our opinion the most important external factors of competitiveness are the investment climate, the level of competition in the interregional and international markets, the geography of productive forces. Quality of management, innovative strategy of the firm, investment directions, labor relations and qualifications of employees, ownership structure and others belong to the internal factors of competitiveness. The investment climate as an external factor of competitiveness has got an essential influence on production costs, the level of which depends on the position of the firm in domestic markets and in relation to competitive countries.

Table 1. Classification of competitiveness factors of the region

\begin{tabular}{|c|c|}
\hline Approaches & Factors \\
\hline resource & $\begin{array}{l}\text { - human } \\
\text { - capital } \\
\text { - entrepreneurial } \\
\text { - informational }\end{array}$ \\
\hline subjective & $\begin{array}{l}\text { - population as a consumer } \\
\text { - enterprises and organizations as producers } \\
\text { - enterprises and organizations as intermediators } \\
\text { - state and municipal institutions as governing bodies, as consumers and producers }\end{array}$ \\
\hline structural & $\begin{array}{l}\text { - economic sector } \\
\text { - sectorial structure } \\
\text { - market structures } \\
\text { - production and social infrastructure }\end{array}$ \\
\hline institutional & $\begin{array}{l}\text { - economic institutions } \\
\text { - legal institutions } \\
\text { - social institutions } \\
\text { - cultural institutes }\end{array}$ \\
\hline $\begin{array}{l}\text { communicative (from the point of view } \\
\text { of economic agents' relations) }\end{array}$ & $\begin{array}{l}\text { - economic, financial } \\
\text { - market (competition) } \\
\text { - non-market (partnership) } \\
\text { - social }\end{array}$ \\
\hline
\end{tabular}

Competition is the main external factor of competitiveness. There is no competition in natural monopoly sectors. Low level of competition leads to innovative passivity, technological lag, high costs, and reduction of competitiveness. For instance, the degree of fixed capital depreciation in the country on average exceeds 30$40 \%$, and the coefficient of renewal does not exceed $2-3 \%$. The measures taken to develop competition at the sectorial and territorial level are not enough as they do not have a proper influence on the competitiveness of firms.

It is necessary to note another important external factor of competitiveness - geographical location of enterprises that forms a regional polarization in the level of competitiveness, spatial inequality in the competitive advantages of getting access to tight resources (quality labor force, sources of investments, energy, construction industry, etc.).

Investment and innovation activities of firms are the most important internal factor of competitiveness. (Bezpalov et al., 2019). However, as it has already been noted, fixed capital in the vast majority of enterprises has got a high physical and moral deterioration, and investment activity of enterprises remains very low. Many innovative products and technologies of domestic and foreign scientists are not used. It is obvious that mechanism of stimulating innovative activity of enterprises is not created at the proper level, which is obliged to assist to accelerate technical and technological development through preferential taxation and lending, to allocate funds for the introduction of scientific and technological achievements in the production, to give moral and 
material encouragement and other methods of financial support for firms that not only introduce domestic and foreign innovative products, but also actively carry out research and design works.

At the same time viability of priority financial support for new enterprises equipped with advanced technology is obvious rather than existing ones, burdened with the traditional structure of fixed capital.

One more internal factor of competitiveness is the effective use of investments.

Labor relations and qualification of employees are considered to be an essential internal factor of competitiveness. It should be noted here that market laws have got a significant influence on the production relations in the sphere of labor resources and increase the requirements for the quality of labor force. In market conditions, where there is competition and intention for maximum profit, firms have to search ways to reduce production costs. Due to limitation of funds for renewal of fixed capital firms are trying to reduce costs through saving fluid capital, including a reduction of the number of employees, a reduction where possible, in wages, funds for social development, labor safety and security.

At the same time there is an acute shortage of skilled personnel of working professions because of the termination of many vocational schools work. In order to solve this problem, investments for external and internal training are allocated what is a necessary condition for supporting competitiveness (Adamczyk et al., 2019).

Finally, structure of property, quality of functioning of public services, industrial and social infrastructure make influence on the competitiveness of the region. These factors indirectly affect the change of competitive positions of the territory through the living conditions of the population.

It seems that competitiveness can be defined as the ability to create conditions for steady development of the region. Two concepts - "competitiveness" and "steadiness" are interrelated and interdependent as the first is the main indicator of steady development of the region. The higher its level, the higher the degree of its steadiness and assessment of the factors of its competitiveness development, the possibility of effect of the regional administration on its components.

It is reasonable to use the model of "national rhomb" proposed by M. Porter. According to this model, the role of the region in creating competitive advantages can be researched in four interrelated directions (determinants) that form a "regional rhomb" (natural resources, capital, skilled workers, infrastructure). We have added two more - information and entrepreneurial talent. Conditions of the demand include the level of income, elasticity of demand, demands of customers to the quality of goods and services. Related and supporting sectors provide the enterprises with necessary resources, components, information, banking, insurance and other services.

Strategies and competition create competitive environment and develop competitive advantages. Based on this model we made a scheme of six main parameters, taking into account the effects of internal and external environment that affect the development of competitiveness in the region (Picture 1). It is seen from the diagram that each of the parameters is in relationship and interaction with internal environment of the region. In the management the external environment is called direct and indirect contacts of the object. 


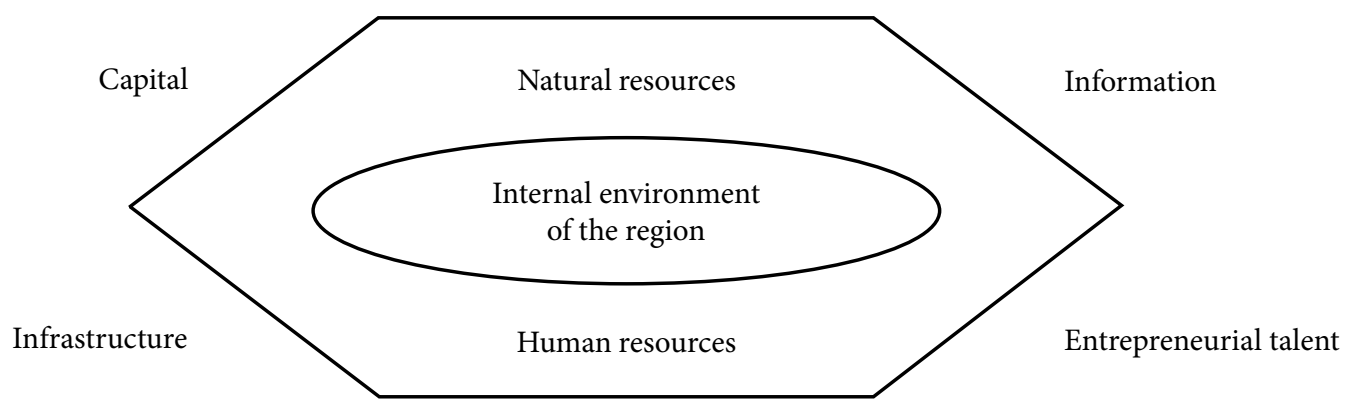

Picture 1. Factors of development of the region's competitiveness using the possibilities of external and internal environment

It consists of microenvironment (direct contacts) and macroenvironment (indirect contacts). Parameters have got a different degree of influence on the competitive advantage of the region and its further development (Abasheva, Sulaev, 2019).

We consider development of the region's competitiveness in four stages: competition based on factors of production; competition based on investment; competition based on innovation; competition based on wealth.

In modern market conditions, it is reasonable to take the level of investment with further transition to innovative development of the region as a basis. Today there is an objective necessity and the demand to fill the region with innovations of the attracted investments. Scientific knowledge, education, factors of production development, factors of formation of innovative potential have got a great importance in creating a competitive advantage of the region (Cheung, de Haan, 2013).

The first three stages ensure economic growth, the latter conditions growth in the future. In our opinion it is possible to take the criteria which characterize the level and quality of life of the population: income, education, health, environmental conditions as a basis in determining the competitiveness of the region.

The potential of the region is realized as a result of the functioning of the regional market which should involve all available own resources in the reproduction process and effectively use them. Special attention should be paid to the regional market, the system of prices through direct and reverse links operating in competing regional markets and thus a single market and pricing system conforming to this market is gradually formed.

This process is sophisticated and long-standing as there are attempts of some regions in order to solve their economic problems with the help of favorable prices at the expense of other regions (in the extraction of fuel and raw materials, in oil refining or construction). Further through the pricing mechanism in each market segment (labor, resources, goods and services, financial) prices are set which reflect both the cost of the main factors of production and the cost of ready products and services.

The pricing mechanism in the region refers to the process of pricing in certain segments of the regional market taking into account the influence of state and regional managing bodies on economic entities.

During determination of the region's competitiveness supply chains were studied (Wen et al., 2018). They determine the consistency and interrelation of the regional market through the pricing mechanism having ensured the competitiveness of the region and steady development.

Enterprises themselves have to create and get a competitive advantage in the regional market. Local authorities are not able to form or influence sufficiently on the institutional structures that are surrounded by the enterprises working there, however they must create the conditions that allow businesses to achieve competitive advantage. It is reasonable to note that the regions reach absolute and comparative advantages due to their differences, not the similarities. Each region has its own specific set of competitive sectors. 
As a result, it can be supposed that in the region where the sectorial structure of the economy has adapted faster to market methods of economy, where the administration supports the structure-forming enterprises and performs a reasonable economic policy, the pricing mechanism provides a balance of regional demand and proposals and contribute to the growth of competitiveness of the region.

The volume of GDP in 2018 comprised 59614 billion tenge, according to forecasts, in 2019 the growth of real GDP can comprise 3.2-3.9\%. The key sectors of Kazakhstan's economy are trade (17\%), production and processing of oil and gas (15\%) and other processing productions $(11 \%)$. The share of the sectors related to oil and gas field in GDP comprised 21\%.

The average gross value added per one employed in the economy of Kazakhstan comprised 6383 thousand tons in 2018. In 2018, the average nominal salary in Kazakhstan reached 176,000 tons per month which is $17 \%$ higher than in 2017, the net inflow of foreign capital comprised $\$ 23$ billion. Key investors in Kazakhstan are the Netherlands (30\% of total foreign investment), the USA $(22 \%)$ and Switzerland $(10 \%)$. More than half (56\%) of foreign investments are in the extractive industry, namely - oil and natural gas production (50\%). Kazakhstan's export of goods exceeds the import almost double. The main trading partners are Russia (19\% of the total turnover of the country) and Italy (14\%). Key categories of the export: oil and oil products - 70\%; metals and their products $-14 \%$; food products $-5 \%$. Key categories of the import: machinery and equipment $-40 \%$; products of chemical sector- $16 \%$; metals and their products $-13 \%$.

The regional market is the initial category for the analysis of regional competitiveness. In this regard, the economic category "competitiveness of the region" is considered with further access to the features of the pricing mechanism. The increase in the living standard of the population identified as the main criteria for the competitiveness of the region mainly depends on the level of its income (salaries, social payments, benefits) which are formed in the labor market.

The research of the region's economic growth and real standard of living of the population in the region involves the measurement of income, first of all salaries with prices in the market of goods and services. Salaries being an element of production costs for the region mainly depend on the efficiency of its production.

In the context of this, it is necessary to note that the leading role in achieving the competitive steadiness of the region belongs to clusters. According to the classical definition, clusters are geographically concentrated groups of interrelated enterprises, specialized service providers and also uncommercial organizations and institutions related to their activities in certain areas which compete but at the same time complement each other (Mogilevskii, Akramov, n.d.).

Particularly clusters create the critical mass that is necessary for competitive success in many fields. Clusters are a characteristic feature of any well-developed economy and that is why they are an essential component of economic development.

Use of the cluster form of business organization is most essential at the regional level due to the necessity for close contact between the cluster members which presumes some territorial unity. Location in one territory allows not only to meet quickly, discuss a common task, quickly solve the problem, but also to determine that direction of activity which is the most competitive for the region now and will be beneficial in the future.

Besides, the region has got a strong joint advantage if it has well-functioning institutional and communication networks, public-private partnerships that are adapted to the needs of the business world. All this encourages the development of interaction, exchange of information, initiatives in regional economic structures, stimulates synergy, and generates new knowledge and ideas.

In order to identify the possibilities of cluster technology it is necessary to analyze the competitive steadiness of enterprises in the region, which is understood as the strengthening of the positions of economic entities in 
this environment, their ability to support their own competitiveness in the long term using the possibilities of the external environment. Assessment of the potential and success of clustering in the region assumes quantitative analysis of statistical data and qualitative analysis of the availability and composition of the resource base, sectorial specialization necessary to provide competitiveness in certain areas.

It is necessary to note the viability of the analysis of the competitive steadiness of the region, supplemented by the analysis of the competitive steadiness of the field, that is, a group of enterprises in the region which produce homogeneous or technologically almost homogeneous products. It is also necessary to pay attention to the possibility of creating production chains from the processing of raw materials to the ready product.

The economic behavior of any region and also economic entities of all ownership forms is now viewed through the prism of increasing regional competitiveness through preserving and using existing, creating and realizing new competitive advantages. Regions compete in order to attract and retain companies, skilled personnel, private capital and investments, state funds and clients (Nifontova, 2019).

The region will have absolute competitive advantages if: 1) it has got the best technological, institutional and infrastructural and social assets; 2) these advantages come from outside but work for the benefit of certain firms; 3) there is such state of things in which even in case of changes of pricing factors of geographical redistribution of economic activities will not occur (Nedim et al., 2018). The given set of signs of competitiveness of territorial education shows the presence in the territory of certain properties that are in demand or particularly appraised by the consumer. In this way, correspondence with these requirements and the level of characteristics of the region determine its competitiveness. Certainly, competitive positions of the region are determined by the competitiveness of fields that make up the structure of its economy and located on the territory of enterprises, firms, companies, institutions, etc.

Analysis of the region's economic environment allows to identify the conditions more completely that contribute to the development of competitiveness in the current social and economic conditions. The region's economy is an economic complex, an integral territorial economic system where the leading role belongs to the fields of market specialization. It is necessary to consider the region not only as a set of natural, human, financial, production resources, but also as a subject of social and economic relations, able to self-management which allows us to talk about the management of competitiveness at the regional level and the economic environment of the region should be understood as a set of sectors in their ratio and dynamics.

As large entities of property and economic activity regions become participants in the competition in the markets of goods, services and capital. The region as an economic entity interacts with national and transnational corporations. Location of headquarters and branches of the corporation, their pricing mechanisms, distribution of working places and orders, transfers, revenues, taxes, etc. make a strong impact on the situation of the regions.

At the present moment, domestic and foreign researchers have accumulated some specific experience in analyzing the competitiveness of territorial structures. Thus, in the United States only, one of the most widespread forms of such assessment of states and cities is the annual development of so-called statistical maps containing four generalizing indexes: the index of economic effectiveness, the index of business viability, the index of growth potential, the tax and fiscal index (Gurban, 2015).

The method of analysis of the regional economy is also widespread through the comparison of competitive advantages. In this case evaluation of the development level of the territory is made on the basis of such criteria as the availability of natural resources, availability of raw materials, geographical location, qualification of the labor force, the availability and condition of fixed assets, the development of regional consumer and financial markets, the policy of local administration, the level and quality of life.

Various researches are carried out in order to identify the main trends in the development of regions, evalu- 
ate their level of development to make further offers to improve competitiveness including: a comprehensive analysis of the development of the region as a component of the social and economic system of the country; a retrospective analysis of the economic development of the region as an independent economic agglomeration; an integral estimation of the potential of the region.

At the same time the following principles of evaluation of the region's competitiveness are used in the analysis: 1) presence of purposes and objectives of the regional system, their realizability; 2) development of methods of indicative planning by regional structures and the reality of plans; 3 ) optimality of the division of powers and responsibilities of various bodies; 4) skillful regulation of economic entities in the territory, effective control of the execution of all programs and projects in the region (Savrukov, Savrukov, 2017).

At the stage of innovative development for Kazakhstan the most important task is to improve the structure of the economy of the country and its regions, to provide effective functioning and big resulting of the invested labor and capital (Dnishev, Alzhanova, 2015). Such orientation is in line of State programs and evaluation of the region's level of development is very important for us as this constitutes the integrity of the country.

The choice of indicators for the analysis of the regions' competitive positions was executed in the following sequence: stage 1 - determination of the comparison base in conformity with the purpose of evaluation; stage 2 - measurement of the level and dynamics of to be estimated indicators; stage 3 - checking of the results of the 1 st and 2nd stages for comparability; stage 4 - formulation of the final evaluation of the level and dynamics of indicators.

During analyzing the level of the region's competitiveness it is necessary to pay attention to: formation of equal institutional conditions, overcoming differences in the level of the regions' economic development; sectorial principle of the region's specialization, restructuring of the economy in compliance with the innovation and investment policy of the country and also medium-term and long-term programs of economic reforms; strengthening the integrity of the development of the region's economy, widening of the use of progressive forms of spatial organization of production and distribution of the population (Tvaronavičienè, 2018.)

\section{Conclusions}

Analysis of various aspects of the regional economy is directed to identifying the strategy of competitiveness of regional systems (Fedorova et al., 2019). In the analysis of regional economies at the regional level the same macroeconomic indicators are applied as in the analysis of the national economy.

Analysis of the territorial structure of the country's economy allows to evaluate how the distribution of population, national wealth, production, consumption, income and also how strong their competitive position is, the growth of the mentioned indicators runs the growth of the population much more ahead. The main prerequisites of the current trends are a favorable investment climate, rising of prices for industrial products, realization of measures for import substitution, realization of infrastructure programs, provision of tax incentives and preferences in the processing spheres, expansion of consumer demand due to income growth.

\section{Reference}

Abasheva, O., Sulaev, S. (2019). Providing import substitution in the region to solve the problem of food safety. AIC: Economy, Management, 1, 4-14.

Abylkasimova, Zh. A., Alibaeva, M.M., Ramashova, A.N., Gudalin, A.V. (2019). Ways of increasing investment activity of enterprises in the region. Bulletin of the Karaganda University. Series «Economy», 2(94), 129-137.

Adamczyk, M., Betlej, A., Gondek, J., Ohotina, A. 2019. Technology and sustainable development: towards the future?, Entrepreneurship and Sustainability Issues, 6(4), 2003-2016. http://doi.org/10.9770/jesi.2019.6.4(32)

Alina, G.B., Daribaeva, A.K. (2018). Priority directions of industrial-innovative development of Kazakhstan: current state and prospects. Bulletin of the Karaganda University. Series «Economy», 4(92), 122-129. 
Amraoui, B., Ouhajjou, A., Monni, S., El Amrani El Idrissi, N., Tvaronavičienè, M. (2019). Performance of clusters in Morocco in the shifting economic and industrial reforms. Insights into Regional Development, 1(3), 227-243. https://doi.org/10.9770/ird.2019.1.3(4)

Bezpalov, V.V., Fedyunin, D.V., Solopova, N.A., Avtonomova, S.A., Lochan, S.A. (2019). A model for managing the innovation-driven development of a regional industrial complex. Entrepreneurship and Sustainability Issues, 6(4), 1884-1896. http://doi.org/10.9770/ jesi.2019.6.4(24)

Bublienė, R., Vinogradova, I., Tvaronavičienè, M., Monni, S. (2019). Legal form determination for the development of clusters' activities. Insights into Regional Development, 1(3), 244-258. https://doi.org/10.9770/ird.2019.1.3(5)

Cheung, Y-W., de Haan, J. (2013). The Evolving Role of China in the Global Economy https://mitpress.mit.edu/books/evolving-rolechina-global-economy

Development of innovations and progressive technological structures in the economy of Kazakhstan in the conditions of industrial modernization: institutions, mechanisms and priorities (2015). (Ed. F. Dnishev, F. Alzhanova). Vienna, Austria: Association for Advanced Studies and Higher Education "East-West", 532 p.

Dudin, M.N., Frolova, E.E., Protopopova, O.V., Andrey Alievich Mamedov, A.A.,Odintsov, S.V. (2019). Study of innovative technologies in the energy industry: nontraditional and renewable energy sources, Entrepreneurship and Sustainability Issues 6(4), $1704-1713$. http://doi.org/10.9770/jesi.2019.6.4(11)

Fedorova, E A, Chernikova, L I, Musienko S O. (2019). Evaluation of the effectiveness of regional management. Economy of Region, $12(2), 350-362$.

Gurban, I.A. (2015). Ranking of territories as a tool of measuring regional welfare. Economic analysis. Theory and practice.42 (441), $36-51$.

Halkos G., Tzeremes N.G., Kourtzidis S.A. (2015). Regional sustainability efficiency index in Europe: an additive two-stage DEA approach. Operational Research, 15, 1-23.

Kisel'áková, D., Šofranková, B., Čabinová, V., Onuferová, E. (2018). Competitiveness and sustainable growth analysis of the EU countries with the use of Global Indexes' methodology. Entrepreneurship and Sustainability Issues, 5(3), 581-599. http://doi.org/10.9770/ jesi.2018.5.3(13)

Lengyel, I. 2016. Competitiveness of Metropolitan Regions in Visegrad Countries. Procedia - Social and Behavioral Science. 223, $357-362$.

Mizanbekova, S.K., Mizanbekov, I.T. (2018). Improvement of the territorial organization of production and processing of products in the agro-food sector. International scientific and practical conference "Actual problems of steady development of agroindustrial complex" Institute of system research in AIC of NAS of Belarus. 192-196 pp.

Mogilevskii, Roman, Akramov, Kamiljon. Trade in Agricultural and Food Products in Central Asia http://www.ucentralasia.org/Content/Downloads/UCA-IPPA-WP27-AgroTrade-Eng.pdf

Nedim, Yuzbashoglu, Serikbay, Ydyrys, Kozhambekov, Zh. Kelesbayev, D. (2018). Development and current situation of special economic zones in Kazakhstan. The Journal of Economic Research \& Business Administration, 3(125), 127-133.

Nifontova, E. (2019) Methodical bases of selection of perspective projects of AIC in regional target programs. AIC: economy, management, 2, 23-31.

Ohotina, A., Lavrinenko, O., Gladevich, J., Lazdans, D. (2018). The investment climate in Latvia's, Lithuania's and Belarus's crossborder regions: the subjective-objective assessment. Entrepreneurship and Sustainability Issues, 6(2), 767-780. http://doi.org/10.9770/ jesi.2018.6.2(20)

Orynbassarova, Y., Abzalbek, E., Pritvorova, T., Petrenko, Y. 2019. Regional and product profile of post-industrial services in the economy of Kazakhstan. Insights into Regional Development, 1(4), 343-355. https://doi.org/10.9770/ird.2019.1.4(5)

Petrenko, Y., Vechkinzova, E., Antonov, V. (2019). Transition from the industrial clusters to the smart specialization of the regions in Kazakhstan. Insights into Regional Development, 1(2), 118-128. https://doi.org/10.9770/ird.2019.1.2(3)

Savrukov, A.N., Savrukov, N.T. (2017). Methodological approach and criteria for assessing the effectiveness of state management in the regions. Finance and credit, 23,7(727), 388-402.

Tireuov, K., Mizanbekova, S., Kalykova, B., Nurmanbekova, G. (2019). Methods and instruments of government control of grain products subcomplex. Entrepreneurship and Sustainability Issues, 7(1), 763-772. https://doi.org/10.9770/jesi.2019.7.1(54) 
Tvaronavičienè, M. (2018). Toward efficient policy making: forecasts of vulnerability to external global threats. Journal of Security and Sustainability Issues, 7(3), 591-600. https://doi.org/10.9770/jssi.2018.7.3(18)

Tvaronavičienè, M. (2019). Insights into global trends of capital flows’ peculiarities: emerging leadership of China. Administratie si Management Public, (32), 6-17, https://doi.org/10.24818/amp/2019.32-01

Wen, X., Yang, Z., Dong, H., Fan, X., Wang, Y. (2018). Barriers to Sustainable Food Trade: China's Exports Food Rejected by the US Food and Drug Administration 2011-2017, Sustainability, 10(6), Article Number 1712. http://doi.org/10.3390/su10061712

\section{Duiskenova RAIGUL}

ORCHID ID: 0000-0002-7011-8229

\section{Zhumaxanova KARLYGASH}

ORCID ID: 0000-0002-8696-5027

This work is licensed under the Creative Commons Attribution International License (CC BY). http://creativecommons.org/licenses/by/4.0/ 